\title{
Fisherman’s Survival Pattern Toward Poverty
}

\author{
Jamaluddin Hos, Muhammad Arsyad \& Suharty Roslan \\ Halu Oleo University, Kendari, Southeast Sulawesi, INDONESIA \\ Social and Politic Faculty, Department of Sociology
}

\author{
Hasniah \\ Halu Oleo University, Kendari, Southeast Sulawesi, INDONESIA \\ Faculty of Humanities, Anthropology Department
}

Received 25 October 2019 • Revised 8 December 2019 • Accepted 12 December 2019

\begin{abstract}
Traditional fishermen in Indonesia were commonly positioned as the poorest people. Actually, the society had owned the strategy to face the social economic difficulties. Generally, poor people had more spirit of survival because they needed to survive their life. That kind of potency might be in the form of personal-social asset, adaptation strategy and problem solving (coping strategy) used locally based on their house condition. This research aimed to explore the way of poor fishermen to survive, conducted in Tanjung Tiram. Methodologically, this research used qualitative approach focusing on people strategic way to survive toward poverty. The data were collected and interpreted simultaneously. The result showed that various strategy combinations of poor fishermen in surviving were the point between social structure awareness and selfcorrection through reflexive monitoring of action responding to the situation faced. The structural aspect included unbalance economy access and patron-client relation which limited the fishermen's ability to increase their social economic status exploitatively. That condition created adaptive behavior such the optimality of coastal resource in their environment involving the whole members of family to earn livelihood. These three strategies became the common thing among them to survive toward social economic crisis.
\end{abstract}

Keywords: social, defense, livelihood strategy, poor fishermen.

\section{Introduction}

The fishermen have significant existence for Indonesia as a Maritime Country because two third of Indonesia is marine (Harun, 2013). Indonesia marine has high potency of wealth. The potential of marine wealth in Indonesia causes the society suspends their life as fishermen. Ironically, most fishermen family placed the lowest and the poorest status in Indonesian social structure. In Indonesia, fishermen are categorized economically, socially, politically as marginal society (Muflikhati, Hartoyo, Sumarwan, Fahrudin \& Puspitawati, 2010). The life of coastal people is commonly poor because their life depends on the nature condition. The condition of marine resource has been degraded until it becomes crucial problem for fishermen (Prihandoko et al., 2012). The factors of fishermen poverty are not only related to fishery fluctuation, limited financial capital

(C) Authors. Terms and conditions of Creative Commons Attribution 4.0 International (CC BY 4.0) apply. Correspondence: Jamaluddin Hos, Halu Oleo University, Social and Politic Faculty, Department of Sociology, Kampus Hijau Bumi Tridharma, Anduonohu, Kec. Kambu, Kota Kendari, Sulawesi Tenggara 93232, INDONESIA. E-mail: jamaluddin_hos@uho.ac.id. 
and exploitative production but also the negative impact of fishery modernization that cause high marine resource draining. The most essential impact that fishermen faced is the lowering of their income (Widodo, 2011) These facts become ironic issue in Maritime country such Indonesia.

Tanjung Tiram village is one of maritime village located in coast of North Moramo, South Konawe, Southeast Sulawesi. Most people in that village are poor fishermen. Their weakness and poverty become the main problem for 34 heads of family or around 99 people in Morawo (Hos \& Arsyad, 2012).

Actually, the society has owned the strategy to face the social economic crisis. Generally, poor people have more spirit of defense because they need to survive their life. That kind of potency may be in the form of personal-social asset, adaptation strategy and problem solving (coping strategy) used locally based on their home condition. Hence, this research focused on their way of responding the problem. These ways become the strategy of the fishermen to fulfill their necessity. Because poor fishermen are in certain social habit that is full of beliefs, values and norms, therefore it is important to take attention to their socio-cultural context. Good understanding of poor fishermen condition is expected to give positive contribution in binding and empowering coastal society.

\section{Theoretical framework}

This research refers to structurasionistic paradigm developed by Anthony Giddens. This perspective does not see the structure and agent as two dichotomy things therefore social practices are created through structure-agent dialectic in which structure is not determinant for people or vice versa. The theory of structuralism refuses the view of structural-positivistic that ignores subject. This theory also refuses to rule out the meaning of structure as the view of voluntary-interpretative perspective.

For Giddens, the main object of Socials is not about whole things, structure, and individual but it is about the meeting point of them. Herry re-explained Ginddens's opinion that "it is the continuous social practice that is structured based on time and place" (Herry-Priyono, 2003). The theory of structuralism does not look at the structure and agent as two dichotomy things that create dual structure. Both structure and agent are related dialectically and continuum that create dual structure (duality structure) (Ritzer, 2004). Structuralism is a link between structure and social action. The relationship of social action to the structure cannot be explained by subordinating one of them. All social actions require structure and the whole structure requires social action. Agents and structures are interrelated and interdependent in human activity.

Giddens sees three major clusters of structural principles: (a) signification structures including symbolic schemes, meanings, mentions and discourses; (b) dominant structures that include schemes of mastery over people (politics) and goods (economy); and (c) justification structure (legitimacy) which concerns the scheme of normative or rule of law (Herry-Priyono, 2003).

In social practices, these three principles are related to one another. Signification structure also includes the structure of domination and legitimacy. The significance scheme in which "the one leading the mass organization is leader" would concern to the schemata of dominance in which "leader's authority is over the citizens", and also the legitimacy scheme in which "the leader has right to bring organization name in relation to other".

The signification structure needs more attention in term of the dominance and legitimacy. In contrast, dominance structure always relates to significance, legitimacy, and legitimacy structure that must be related to significance and legitimacy. 
The structure, as a result of social practice repetition, can only be formed through the repetition of certain discourse practices that are the signification schemes, the repetition of various practices of mastery, and the repetition of the practice of imposing sanctions against violations of the norm. Similarly, the structure is as a means of social practice. Social actions and practices such as speaking, discussing or writing presuppose certain signification / signification structures. The mastery and use of financial assets (economic) or the president's control of ministers (politics) presupposes a structure of dominance. The same pattern also applies in sanctions against students who do not do homework by teachers involving the structure of legitimacy.

On the actor's side, Giddens distinguished three internal dimensions of actors related to the consciousness hierarchy: the unconscious motives, practical consciousness, and discursive consciousness (Giddens, 1984). Unconscious motive is a desire to do direct action, but not the act itself. Discursive consciousness refers to the individual's capacity to reflect and to provide a detail description of his actions. Practical consciousness refers to a cluster of practical knowledge that is rarely questioned and cannot always be parsed.

Among the three dimensions of the perpetrator's consciousness, practical consciousness is the key to understand the process of how social actions and practices gradually become structures, and how they restrain and enable social action/practice. Social reproduction takes place through the repetition of rarely questionable social practices (Herry-Priyono, 2003).

Human is not only to reproduce but also to bargain and to modify the structure. Human being has the ability to introspect and to observe themselves through reflexive monitoring of action, both the activities of individual actors themselves and the activities of other actors. Changes occur when the monitoring capacity extends and happen "de-routine" leadings to structural obsolescence. It means that the schemes that already become the rules and resources of social action and practice are no longer sufficient to be used as a principle of meaning and organization of various ongoing social practices, or that is being fought for new social practices (Herry-Priyono, 2003).

Based on the point of view above, the strategy of livelihood in case of survival is seen as obscure in vacuum world. Yet, it is a certain social habit that is full of beliefs, values and norms. On other words, it always stands on certain socio-cultural contacts. Society will always have culture and behaviors. However, human interpret and consider subjective consideration rather than live their life systematically. Hence, fishermen's social reality is closed to subjective dimension. That case will cause the variety of behavior including the livelihood strategy of fulfilling their social economy needs.

The social reality as explained above is in line with the Giddens' theory of structuralism that becomes theoretical orientation in this study. The structuralism is placed as a shadow order and common standards that are taken into account or considered by the fishermen in daily social activities, especially in taking the livelihood strategy as a survival of poor fishermen to respond unfavorable conditions.

\section{Fishermen, poverty and survival}

Fishermen are people who actively engage in fishing activities, either directly or indirectly as their livelihood. Geographically, the fishing community is a living, growing and developing community in coastal areas. As a social unity, fishing communities have value systems and cultural symbols as a reference to their daily behavior. Most coastal communities, either directly or indirectly, depends their life survival on managing the potential of marine resources.

Kusnadi (2002) classified fishing communities into several typologies. First, in terms of mastery of production equipment or fishing gear (boats, nets and other equipment), fishing 
communities are divided into owners and workers. The workers do not have production tools whose activities only contribute to their labor by obtaining very limited rights. Second, in terms of capital investment rate scale, fishermen are divided into two categories: higher and lower fishermen. Higher fisherman is the one who has more capital investment in fishing business while the lower fishermen positioned the opposite. Third, judging from the level of equipment technology used, the fishermen are also divided into two categories: modern and traditional fishermen. Modern fishermen use more sophisticated fishing technology than traditional fishermen.

Based on the typology, poor fishermen generally do not have adequate resources (tools of production), even if the ownership is usually a very simple technology (traditional), no capital that can be invested in a more productive fishery business. Concerning the concept of poor fishermen, they usually have quite prominent features although there is no clear definition and criteria as opposed to prosperous. First, the activities are more intensive labor even though they have used outboard motors with simple fishing gear. Second, the technology they used for marine process products is also simple. Third, their level of education and skills are still very low. Fourth, the involvement of pre-age children and fishermen's wife in household economic business is high (Indrawasih, 1993).

Every human being and society has a way to stay alive. Humans work and adapt constantly to find the best strategies. According to Scott (in Sugihardjo, 2012), the traditional poor peasants' survival strategy is "safety-first". For poor peasants who are social-economically vulnerable, decreasing or even cropping failures will have a devastating impact on the survival of their families. Under such conditions, farmers avoid risks and focus on the possibility of decreasing crops, not on maximizing profits.

As the effort of survival and necessary fulfillment, poor fishermen involve all family members in economic activities to response the poverty. According to Dharmawan (2007) every family always strives to maintain its life status through various ways of survival which he called as a livelihood strategy - the way of survival or status improvement of life. Livelihood strategies are tactics and actions built by individuals or groups in order to sustain their lives by keeping in mind the existence of social infrastructure, social structure and cultural value systems.

Similar to (Dharmawan \& Zid, 2011) showed that the involvement of all family members in economic activity, ecological adaptation and job diversification are another livelihood strategies for fishermen to survive and to improve their welfare. The diversity of livelihood strategies built by individuals and groups is motivated by the strength of infrastructure (institutional) and the supra-structure (social) power and social structure (social relations patterns).

Slamet Widodo's research (2011) also showed that the economic strategies and social strategies are always applied to fulfill the needs of poor households. The economic strategy is carried out by fishermen with a double income pattern, the utilization of domestic labor and migration. On the other sides, the social strategy is done by utilizing existing kinship ties. As viewed from the base of the livelihood, poor households make diversification efforts in all sectors on farm, off farm and nonfarm. Meanwhile, Patriana and Arif Satria's research (2013) found that adaptation and economic strategies to respond climate change are: climate adaptation by fishing in other areas; adaptation of coastal resources by fishing in mangrove areas; adaptation of human resources allocation in the household which includes the optimization of the household workforce, the double income pattern of the farmers, and the transportation service using the fishing boat; and switching professions.

Every people including fishing communities, owns a culture that organizes the meaning and behavior of everyday life. Culture is a system of ideas or cognitive system that serves as a guide of life, reference patterns of social behavior, as well as a means to interpret the events 
that occur in the environment. It is in accordance with Sanapiah S. Faisal (1998) study that the working culture of farming communities in Sumbawa explained that the purpose of farmers' production cannot be simplified for the purpose of subsistence in the economic sense because the concept of basic needs itself cannot be separated from social/cultural constructs. The concept of work is a cultural phenomenon whose meaning depends on local social and cultural constructs. Therefore, Faisal agrees with Brush and Dalton about the lack of relevance to the use of conventional formal economic concept of work, including the concept of unemployment to be applied blindly to the peasant world. The same thing is also applied to fishermen because the economy itself is an integral part of social organization in people's life.

\section{Conceptual framework}

By using the concept of duality structures, poor fisherman's survival as a sociological reality is understood as: First, due to structure - the social system establishment (politics, social, economic and cultural) described by Giddens in three major structural groups: signification, domination and legitimacy. Structures that constrain and enable the poor fishermen actors may cause them to perform actions/livelihood activities. Second, due to the actions of poor autonomous and creative fishing actors based on the level of consciousness: unconscious motives, practical consciousness, and discursive consciousness.

Referring to the concept of the duality structure, the most important implications of this research are: observation and study focusing on social practices patterned as regularity in everyday life; paying sufficient attention to aspects or dimensions of a cultural nature in order to understand the structured belief system, values, and norms and encompass the practitioners of social practice; and to place the perpetrators of social practices (fishermen) as free and creative agents who constantly monitor their own thoughts and activities and their social and physical context. Thus, this research is oriented towards understanding the pattern of poor fisherman's survival according to the perspective of Emik based on the fisherman's perspective as the subject of cultural actors themselves. In this case, understanding the fisherman's defense pattern is related to the meanings based on the views, beliefs, values, interpretations, propositions or everyday theories that live and grow among the fishermen themselves.

\section{Research method}

This research used qualitative approach in which its method did not only collect the data quantitatively but also by understanding the phenomena. The main character of this approach is inductive method. This method is based on logical procedure which is started from certain proportion as the result of observation and followed by general conclusion. The conclusion studies about human's position and understanding their behavior. The observation and interview became the main data collection technique while the researcher became the main instrument of the research.

Understanding fishermen's life survival means trying to understand their livelihood strategy. This case of understanding is considered as a research whose approach really considers the understanding aspect rather than the amount of scale aspect.

There were two data collection of understanding fishermen's life survival: observation and in depth interview. The observation was conducted by viewing the table of life including social practices, behavior, and their sharing related to the fulfillment needs strategy. In case of finding the table of life itself, the observation result would be strengthened by in depth interview. This research implemented Giddens's analysis of strategic conduct for structurasionictic (Giddens, 1984). Thus, this research would focus on the activities of fishermen in contextual situation. 
In addition, data validity testing was conducted by implementing triangulation. Meanwhile, the data sampling applied snow-ball sampling - collecting data continuously. On other words, the data would be continuously collected until it did not find any new information concerning the data target.

The process of data collection and data interpretation would be done in the same time during the research. Data analysis is the process of organizing and arranging data into pattern, category, and basic explanation so that the result may create substantive theory (Moleong, 2017). The data analysis used was interactive model offered by Huberman and Miles (1994). The process cycle of this study included data collection, data reduction, data presentation and verification.

Data reduction was done by selecting, focusing on sampling and transforming data from field notes. Data presentation is a group of arranged information which then creates action and conclusion. Data verification is an effort of finding conclusion concerning the patterns, explanations, configurations, causal effects and proportions.

Theory development is one of the aims of this study which refers to basic concept of the discovery of grounded theory proposed by Strauss and Corbin (1990). The implementation of this concept was combined with Giddens's fundamental thought of hermeneutics by following the facts and data development.

Coding technique was applied in grounded theory, such as: open coding, axial coding and selective coding (Suyanto, 1995). Open coding identified categories by naming and labeling which was followed by attributes and dimension identification. Axial coding meant revealing categories. These categories were positioned as (a) cause, (b) indication, (c) complex condition which cause action and interaction, (d) intervention; structural condition that might either facilitate or complicate the process, and (e) action or interaction to achieve goals. The result of axial coding was then developed in a more holistic construction and theoretic through selective coding. In this case, selecting categorization was done to string up chains of story.

\section{Results and discussion}

Generally, fishing communities in the village of Tanjung Tiram was a traditional and poor fishermen's communities. They utilized fishery resources with simple traditional technology and limited business capital. Fulfilling the basic daily needs of the family was the main orientation, especially the needs of food. Limitations of technology owned to make the movement of traditional fishermen was only able to be operated in coastal waters. Whereas, the condition of coastal resources had also been degraded which caused these traditional fishermen were increasingly marginalized with low quality of life.

Poor society had owned strategy to face socio-economy difficulties. Despite being in unfavorable conditions due to poverty, there was still a zest for life. They applied coping strategies to respond the condition of all the elements to survive. The pattern of poor fishermen's survival in the village of Tanjung Tiram manifested as a strategy of poor fishermen's families to fulfill their livelihood needs and as the socio-economic adaptation of fishermen's families in fighting poverty. Some patterns of poor fisherman's survival were as follows:

\subsection{Optimizing the utilization of coastal resources}

One form of economic strategy to fulfill the needs of food was the utilization of coastal resources to produce various commodities of economic value without going deep into the open seas. Crabs became the alternative productions when they could not go fishing on the sea. The 
fishermen usually looked for crabs when the sea water was low tide which in its local language is called meti. Meti water occurs twice a month for five to seven days.

In the low tide season, fishermen also continued to sail by using a fishing gear. They did it in both low tide and tidal season. Besides those two seasons, fishermen in Tanjung Tiram Village also considered the shady season and the high wind season. Shady season was considered as ideal time for fishing while the high wind season and along with the tide was considered as a famine. However, this community kept searching for crabs to cover the needs of daily living.

Information from some informants indicated that ideal conditions for fishing were in the shade season even in the light of the moon. The fishermen implied that they were still able to get fish along the shade. However, during the moonlight, the types of fish that could be caught were limited to certain types and ways such as white fish and catambak.

Based on the above explanation, fishermen in Tanjung Tiram Village always tried to utilize coastal resources optimally by doing various strategies and adaptation of environment. It was in line with Patriana and Arif Satria (2013), optimizing the utilization of coastal resources was a process of adaptation and reactive economic strategy to face environmental changes. Related to Giddens's view, optimizing the use of coastal resources had become a recurrent and social practice in time and space (Herry-Priyono, 2003). From the fisherman's point of view as an agent, the social practice derived from the practical consciousness pointing to the rarely questionable cluster of practical knowledge that became a routine and gradually part of a work culture organizes the meaning and behavior of fishermen in daily life (Faisal, 1998).

\subsection{Optimizing domestic workers}

Another economic strategy used to deal with the famine season was optimizing the utilization of family labor, housewives and children. This involvement was to look for crabs and shellfish when fish season was not stabilized and the frequency of fishing at sea was decreased. The involvement of family members other than the head of the family in the fulfillment of living had a significant role in saving the family economy. The optimization of domestic workforce was also seen in the activities of making snack cake. Some fisherman's housewives made cookies to make their children sell it in their school.

Meanwhile, male teenagers were active as construction workers and/or become paulaula (loader/lifter of rocks to the truck) when the construction project arrived. North Moramo was known as one of the stone mining areas. When the construction projects raised, trucks and cars often passed by to carry rocks from Moramo to Kendari.

Utilization of fisherman's household worker to fulfill the living necessity in famine came from discursive awareness. Human is not only to reproduce but also at the same time bid and modify the structure. Fishermen had the ability to introspect and to observe themselves through reflexive monitoring of action, both the activities of individual actors themselves and the activities of other actors. Changes occurred when the capacity of monitors extended therefore "deroutine" took place to lead structural obsolescence. Thus, the schemata which was already the rule and the resources of social action and practice was no longer sufficient to be used as a principle of meaning and organization of various ongoing social practices (Giddens, 1984). This was an economic strategy of poor fishermen in order to fulfill the needs of poor households (Widodo, 2011). 


\subsection{Double earning pattern}

Besides the optimization of household labor through the involvement of family members in livelihood, some fishermen in the village of Tanjung Tiram at certain times also applied a double income pattern. This was also one of the economic strategies as described by Widodo (2011) as an effort to fulfill the needs of fishermen survival to face unfavorable social conditions of their economy. There were several jobs applied to fulfill the living needs, including: stone breakers, construction workers, gold miners and gardening.

Based on the observations and interview results obtained, working to break the stone was done by buying stones in spindles then broken down into coral. Building construction work was usually carried out in power project development in Moramo or Kendari. Usually, they were invited by friends or people who had deliberately came to the Village of Tanjung Tiram to find labor. One popular type of worker activity in Moramo was the paula-ula, lifting rocks into truck at a rock mining site.

Many fishermen in Tanjung Tiram village worked as gold miners in Namlea, Timika Papua. They usually worked there for \pm 6 months, during the west wind season and southeast. Being a miner in Papua also facilitated them to access information and network of kinship.

Gardening was also one of alternative jobs for fishermen. They did gardening activities (planting sweet potatoes and corn) as an additional routine everyday by borrowing empty land in the village of Tanjung Tiram which incidentally had not been utilized yet by the owner. This gardening activity was carried out as an effort to ease the burden of the family related to the fulfillment of food needs where cassava and corn were a staple food of fishermen other than rice.

This dual pattern of income was the result of domination structure including the schemes of mastery over people (politics) and goods (economics) that had not been favored by fishermen (Herry-Priyono, 2003). The owner of simple and traditional fishing gear and tools suggested that the acquisition and usage of financial assets (economy) of services were inadequate to fulfill family needs and to sustain the educational development of their children. This condition gave discursive awareness to dive some types of jobs as a strategy to survive although none of the jobs provided welfare for them.

\section{Conclusion}

The poor fishermen in Tanjung Tiram were traditional fishermen with limited access to technology and information. Hence, the pattern of survival that manifested as strategy to fulfill the needs of livelihood and social economic adaptation was still dominated by reactive patterns. The pattern of defense among others means optimization of coastal resource utilization; utilization of domestic workforce; and multiple income patterns. Based on the perspective of structural theory, the poor fisherman's survival pattern as a sociological reality could be understood as a result of established social structure or system and the actions of autonomous and creative poor fishermen actors are based on the level of consciousness: unconscious motives, practical consciousness, and discursive consciousness. Structural aspect is more pressing and hampering the progress of fishery community activities in the Tanjung Tiram. This causes more reactive respond to environmental conditions as a consequence of helplessness. The fisherman agency aspect is also weak that leads to practical consciousness and unconscious motives rather than discursive consciousness. Even if there is discursive awareness among poor fishermen families, it is more reactive to the situation to survive than to anticipate attitudes and behavior to make changes that lead to progress. This suggests that the dialectic of agent structures is not equally balanced in the context of poor fishing communities. 


\section{Acknowledgements}

This research did not receive any specific grant from funding agencies in the public commercial, or not-for-profit sectors.

The authors declare no competing interests.

\section{References}

Dharmawan, A. H. (2007). Sistem Penghidupan dan Nafkah Pedesaan: Pandangan Sosiologi Nafkah (Livelihood Sociology) Mazhab Barat dan Mazhab Bogor. Sodality: Jurnal Sosiologi Pedesaan. https://doi.org/10.22500/sodality.v1i2.5932

Dharmawan, A. H., \& Zid, M. (2011). Fenomena Strategi Nafkah Keluarga Nelayan: Adaptasi Ekologis in Cikahuripan-Cisolok, Sukabumi. Jurnal Sosialita, 9, 32-38.

Faisal, S. S. (1998). Budaya Kerja Masyarakat Petani. Kajian Strukturasionistik: Kasus Petani Sumbawa. Airlangga University.

Giddens, A. (1984). The constitution of society: Introduction of the theory of structuration. Berkeley. In: The Constitution of Society: Outline of the Theory of Structuration.

Harun, M. (2013). Luas Wilayah Negara. Retrieved from invonesia.com website: http://www.invonesia.com/luas-wilayah-negara-indonesia.html.

Herry-Priyono, B. (2003). Anthony Giddens Suatu Pengantar. Jakarta: Kepustakaan Populer Gramedia (KPG).

Hos, J., \& Arsyad, M. (2012). Faktor-Faktor Kemiskinan Keluarga Nelayan di Desa Tanjung Tiram Kecamatan Moramo Utara Kebupaten Konawe Selatan. Halu Oleo University.

Huberman, A. M., \& Miles, M. B. (1994). Data management and analysis methods. In: Handbook of qualitative research.

Indrawasih, R. (1993). Peranan Ekonomi Wanita Nelayan di Maluku. Masyarakat Indonesia, XX.

Kusnadi (2002). Nelayan: Strategi Adaptasi dan Jaringan Sosial. Bandung: Humaniora Utama Press.

Moleong, L. J. (2017). Metodologi Penelitian Kualitatif (Edisi Revisi). In: PT. Remaja Rosda Karya.

Muflikhati, I., Hartoyo, H., Sumarwan, U., Fahrudin, A., \& Puspitawati, H. (2010). Kondisi Sosial Ekonomi dan Tingkat Kesejahteraan Keluarga: Kasus di Wilayah Pesisir Jawa Barat. Jurnal Ilmu Keluarga Dan Konsumen. https://doi.org/10.24156/jikk.2010.3.1.1

Patriana, R., \& Satria, A. (2013). POLA ADAPTASI NELAYAN TERHADAP PERUBAHAN IKLIM: Studi Kasus Nelayan Dusun Ciawitali, Desa Pamotan, Kecamatan Kalipucang, Kabupaten Ciamis, Jawa Barat. Jurnal Sosial Ekonomi Kelautan Dan Perikanan. https://doi.org/10.15578/jsekp.v8i1.1191

Prihandoko, S., Jahi, A., Gani, D. S., Purnaba, I. G. P., Adrianto, L., \& Tjitradjaja, I. (2012). Kondisi Sosial Ekonomi Nelayan Artisanal di Pantai Utara Provinsi Jawa Barat. Jurnal Penyuluhan, 8, 82-91. https://doi.org/10.25015/penyuluhan.v8i1.9896

Ritzer, G. (2004). Teori Sosiologi Modern. Jakarta: Prenada Media.

Strauss, A., \& Corbin, J. (1990). Basics of qualitative research: Grounded theory procedures and techniques. In: Handbook of qualitative research.

Sugihardjo (2012). Strategi Bertahan Dan Strategi Adaptasi Petani Samin Terhadap Dunia Luar. SEPA: Vol. 8 No. 51-182. 
J. Hos et al. - Fisherman's Survival Pattern Toward Poverty

Suyanto, B. (1995). Metode Penelitian Sosial. Surabaya: Airlangga University Press.

Widodo, S. (2011). STRATEGI NAFKAH BERKELANJUTAN BAGI RUMAH TANGGA MISKIN DI DAERAH PESISIR Slamet Widodo. Makara Human Behavior Studies in Asia, 15, 10-20. https://doi.org/10.7454/mssh.v15i1.890 